\title{
An African-American Cystic Fibrosis Patient Homozygous for a Novel Frameshift Mutation Associated With Reduced CFTR mRNA Levels
}

\author{
Lisa S. Smit, Samya Z. Nasr, Michael C. Iannuzzi, and Francis S. Collins* \\ Departments of Human Genetics (L.S.S., F.S.C.), Internal Medicine (F.S.C.), and Pediatrics (S.Z.N.), and the Howard \\ Hughes Medical Institute (F.S.C.), University of Michigan, Ann Arbor, Michigan 48109, and Henry Ford Hospital, Detroit, \\ Michigan 48202 (M.C.1.); Fax: 313-936-2888 \\ Communicated by David Ginsburg
}

\section{INTRODUCTION}

Cystic fibrosis (CF) is characterized primarily by pulmonary disease, pancreatic exocrine insufficiency, and elevated sweat concentrations (Collins 1992). Although best known as the most common autosomal recessive disorder in the Caucasian population, $\mathrm{CF}$ is also present in other populations, such as African-Americans, albeit at a lower frequency. The disease is caused by mutations in the cystic fibrosis transmembrane conductance regulator (CFTR) gene. The most common mutation in Caucasians is a three base pair deletion ( $\Delta$ F508), which accounts for approximately $70 \%$ of $\mathrm{CF}$ chromosomes (Cystic Fibrosis Genetic Analysis Consortium, 1990). Over 150 additional, rarer mutations have been reported (Tsui, 1992a, b), including 9 from Black CF patients (Cutting et al., 1990a, 1992). We report here a novel frameshift mutation in exon 13 of CFTR, identified in an African-American patient.

\section{MATERIALS AND METHODS}

Lymphocyte genomic DNA was obtained from a 30-year-old, female, African-American CF patient. The patient is pancreatic insufficient with a sweat chloride concentration of $104 \mathrm{mmol} / \mathrm{liter}$. Her height is $164 \mathrm{~cm}$ ( $50 \%$ for age), and weight is $53.9 \mathrm{~kg}$ ( $25-50 \%$ for age). Pulmonary function testing revealed severe lung disease with $\mathrm{FVC}$ of 1.6 liters $(44 \%)$ and $\mathrm{FEV}_{1}$ of 0.55 liters $(18.1 \%)$. She is colonized with Pseudomonas cepacia. No family history is available as the patient is adopted.

CFTR exon 13 was amplified from genomic DNA by the polymerase chain reaction (PCR). Standard conditions were used for all PCRs described in this report (Sambrook et al., 1989) with
35 cycles of $1 \mathrm{~min}$ at $94^{\circ} \mathrm{C}, 1 \mathrm{~min}$ at $55^{\circ} \mathrm{C}$, and 2 min at $72^{\circ} \mathrm{C}$. Intron specific PCR primers flanking exon 13, with the addition of BamHI restriction sites, were used: 5'ATACGGATCCTGCTAAAATACGAGACATATTGCA3' and 5'ATACGGATCCTACACCTTATCCTAATCCTAT. GAT3'. The amplified region was screened by chemical mismatch cleavage (CMC), as described elsewhere (Strong et al., 1991), and sequencing, using the Sequenase 2.0 kit (United States Biochemical).

For the diagnostic restriction enzyme digest, DNA was amplified by the PCR with exon 13 specific primers: 5'ATACGGATCCCAATCT. 'TTTAAACAGACTGGAGAGTT3' and 5'ATACCTCGAGCCAGTTCAGTCAAGTTTGCCTGAGG3'. The PCR products were digested with Mboll and visualized in a 3\% agarose gel.

Nasal tissue was obtained from the patient and a normal subject by nasal scrape as described elsewhere (Strong et al., 1992). RNA was extracted from nasal epithelial cells of the patient and a normal subject using RNAzol B (Tel Test), according to the manufacturer's instructions. One microgram of total RNA was reverse transcribed in a volume of $50 \mu \mathrm{l}$ containing $1 \mu \mathrm{g}$ of random hexamers, 200 units moloney murine leukemia virus reverse transcriptase (RT) (BRL), 40 units RNasin (Promega), $50 \mathrm{mM}$ Tris, pH 8.3, $50 \mathrm{mM} \mathrm{KCl}, 8 \mathrm{mM} \mathrm{MgCl}$, and $10 \mathrm{mM}$ DTT. PCR amplification was performed using $5 \mu \mathrm{l}$ of the RT reaction as template and the following CFTR primers: 5'ATACCT-

Received November 30, 1992; accepted January 21, 1993.

*To whom reprint requests/correspondence should be addressed. 


\section{7ins A}

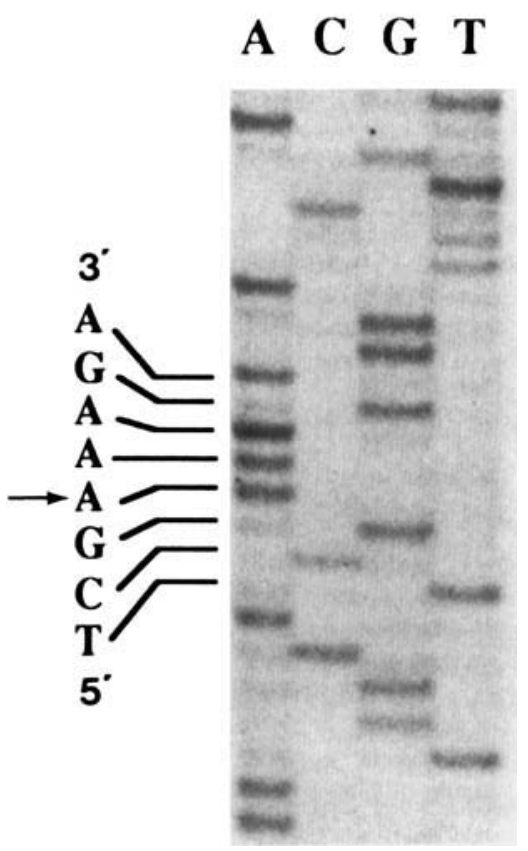

FIGURE 1. Partial DNA sequence of CFTR exon 13 from a patient homozygous for 2307insA. Insertion of an adenine is indicated by the arrow.

CGAGACAACAGGAGAAGGAGAAGGAAGAG3' (exon 18) and 5'ATACCTCGAGGGGCTTAGACTTGCACTT3' (exon 24). A second round of amplification was performed using nested primers: 5'ATACCTCGAGGGCCTCTTGGGAAGAACTGGATCA3' (exon 20) and 5'ATACCTCGAGAGGCTCCTCTCGTTCAG. CAGTTTCT3' (exon 24). As a control for the efficiency of the RT reaction, $5 \mu$ l of RT product was amplified using primers to the $c-a b l$ gene: 5'TCACTGGGTCCAGCGAGAAGGTTTTCCTTGGAGTT3' and 5'TTTATGGGGCAGCAGCCTGGAAAAGTACTTGGG3'. RT/PCR products were visualized in a $2 \%$ agarose gel.

\section{RESULTS}

Exons 9-13 were screened by chemical mismatch cleavage. An insertion of a single adenine at nucleotide 2307 (2307insA) of CFTR was detected in an African-American CF patient (Fig. 1). The resulting shift of the reading frame at codon 726 introduces two consecutive stop codons at amino acid positions 729 and 730 . The mutation also destroys an Mboll site. Restriction analysis revealed that the patient is homozygous for $2307 \mathrm{ins} A$. The frameshift mutation was not found

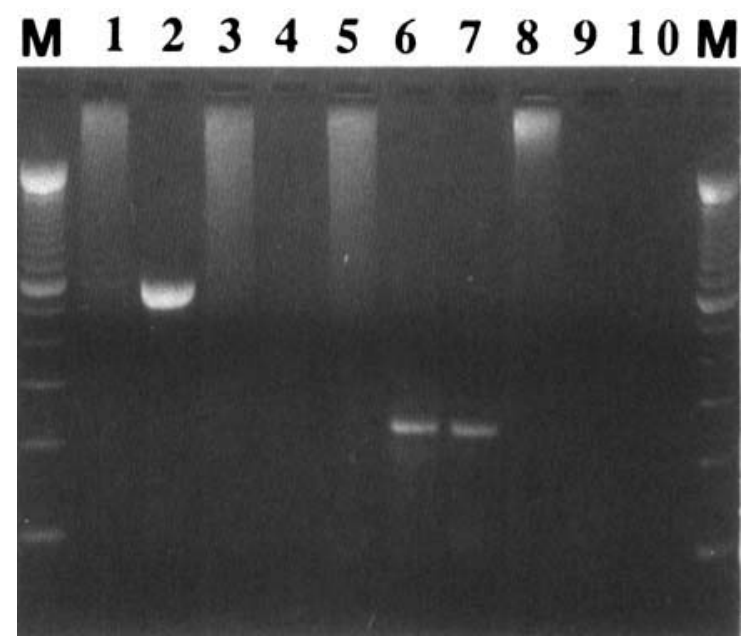

FIGURE 2. Ethidium bromide staining of RT/PCR products. Lanes 1-5: reverse transcription and two rounds of amplification performed using nested CFTR primers. Lanes 6-10: reverse transcription and amplification performed using primers to the c-abl gene. cDNA template for lanes 1, 3, 6 and 8 is from patient (2703insA/2307insA) nasal epithelial RNA. Template for lanes 2, 4, 7 and 9 is from a control nasal epithelial RNA sample. Lanes $3,4,8$ and 9 are controls with no RT added. Lanes 5 and 10 are negative $\mathrm{H}_{2} \mathrm{O}$ controls. $M$ indicates a 100 bp marker ladder.

on 26 normal chromosomes, nor on 32 non- $\Delta F 508$ CF chromosomes.

To examine the mRNA level associated with the 2307 ins $A$ mutation, RNA from nasal epithelial cells of the patient and a normal subject were reverse transcribed. Subsequent amplification of the cDNA revealed that the CFTR message level associated with 2307 ins A was markedly reduced compared to the normal control, while both the patient and the normal subject showed similar levels of expression of the c-abl control mRNA (Fig. 2).

\section{DISCUSSION}

We have identified a frameshift mutation (2307ins A) in exon 13 of CFTR. 2307insA is expected to result in a truncated protein which would lack the second half of the normal protein. Reverse transcription and PCR indicate that 2307insA is associated with severely diminished CFTR mRNA in nasal epithelial cells, although the analysis is not quantitative. The reduced message level probably results in markedly reduced CFTR protein levels as well. This phenomenon is not unexpected as it has been observed for several nonsense mutations in CFTR (Hamosh et al., 1991, 1992) and in other genes (Kinniburgh et al., 1982; Atweh et al., 1988; Daar and Maquat, 1988). In addition, 
this is more common when the nonsense mutation is in a proximal exon, as it is in this case (Cheng et al., 1990).

2307ins A was detected in an African-American CF patient who appears to be homozygous for the frameshift, although hemizygosity cannot be excluded by this analysis. It is possible that the patient's genotype is a result of consanguinity in the family which cannot be assessed since she is adopted. Uniparental disomy, previously described for this region (Spence et al., 1988), could also account of the homozygosity. Clinically, the patient has severe disease, as evidenced by pancreatic insufficiency and impaired pulmonary function.

Other CF patients found to be homozygous or compound heterozygous for nonsense or frameshift mutations have been reported (Cuppens et al., 1990; Cutting et al., 1990a; Beaudet et al., 1991; Ferec et al., 1992; Nunes et al., 1992; Shoshani et al., 1992). They are all pancreatic insufficient yet some of these individuals have had mild pulmonary involvement. The severe lung disease observed in this patient homozygous for 2307insA contrasts with the original suggestion that truncation mutations might have a greater effect on pancreatic function than on pulmonary function (Cutting et al., 1990a). The original observation may reflect the large, genotype-independent variability observed in CF pulmonary function (Kerem et al., 1990) and argues for the use of pancreatic rather than pulmonary status for defining an allele as mild or severe.

\section{ACKNOWLEDGMENTS}

We thank Dr. Robert Stern for clinical assistance and Lap-Chee Tsui for providing normal chromosome DNA. We are also grateful to Theresa Strong for her helpful advice. This work was supported by grants from the Cystic Fibrosis Foundation and the National Institute of Health (DK42718 and DK39690). L.S.S. is a Howard Hughes Predoctoral Fellow and F.S.C. is an Investigator of the Howard Hughes Medical Institute.

\section{REFERENCES}

Atweh GF, Brickner HE, Zhu X-X, Kazazian HH, Forget BG (1988) New amber mutation in a B-thalassemic gene with nonmeasurable levels of mutant messenger RNA in vivo. J Clin Invest 82:557-561.

Beaudet AL, Perciaccante RG, Cutting GR (1991) Homozygous nonsense mutation causing cystic fibrosis with uniparental disomy. Am J Hum Genet 48:1213.

Cheng J, Petrovic-Fogel M, Maquat, LE (1990) Translation to near the distal end of the penultimate exon is required for normal levels of spliced triosephosphate isomerase mRNA. Am J Hum Genet 10:5215-5225.
Collins FS (1992) Cystic fibrosis: Molecular biology and therapeu tic implications. Science 256:774-779.

Cuppens H, Marynen P, De Boeck C, De Baets G, Eggermont E Van den Berghe I, Cassiman II (1990) A child, homozygous for a stop codon in exon 11 , shows milder cystic fibrosis symptoms than her heterozygous nephew. J Med Genet 27:717-719.

Cutting GR, Kasch LM, Rosenstein BJ, Tsui L-C, Kazazian HH, Antonarakis SE (1990a) Two patients with cystic fibrosis, nonsense mutations in each cystic fibrosis gene, and mild pulmonary disease. N Engl J Med 323:1685-1689.

Cutting GR, Kasch LM, Rosenstein BJ, Zielenski J, Tsui L-C, Antonarakis SE, Kazazian Jr. HH (1990b) A cluster of cystic fibrosis mutations in the first nucleotide-binding fold of the cystic fibrosis conductance regulator protein. Nature (London) $346: 366-368$.

Cutting GR, Curristin S,M., Nash E, Rosenstein BJ, Lerer I, Abeliovich D, Hill A, Graham C (1992) Analysis of four di verse population groups indicates that a subset of cystic fibrosis mutations occur in common among caucasians. Am J Hum Genet 50:1185-1194.

Cystic Fibrosis Genetic Analysis Consortium (1990) Worldwide survey of the $\Delta \mathrm{F} 508$ mutation--report from the Cystic Fibrosis Genetic Analysis Consortium. Am J Hum Genet 47:354-359.

Daar IO, Maquat LE (1988) Premature translation termination mediates triosephosphate isomerase mRNA degradation. Mol Cell Biol 8:802-813.

Ferec C, Audrezet MP, Mercier B, Guillermit H, Moullier P, Quere I, Verlingue C (1992) Detection of over $98 \%$ cystic fibrosis mutations in a Celtic population. Nat Gen 1:188-191

Hamosh A, Trapnell BC, Zeitlin PL, Montrose-Rafizadeh C, Rosenstein BJ, Crystal RG, Cutting GR (1991) Severe deficiency of cystic fibrosis transmembrane conductance regulator messenger RNA carrying nonsense mutations R553X and W1316X in respiratory epithelial cells of patients with cystic fibrosis. J Clin Invest 88:1880-1886.

Hamosh A, Rosenstein BJ, Cutting GR (1992) CFTR nonsense mutations G542X and W1282X associated with severe reduction of CFTR mRNA in nasal epithelial cells. Hum Mol Genet $1: 542-544$

Kerem E, Corey M, Kerem B-S, Rommens J, Markiewicz D, Levison H, Tsui L-C, Durie P (1990) The relation between genotype and phenotype in cystic fibrosis - analysis of the most common mutation ( $\Delta F 508$ ). N Engl J Med 323:1517-1522.

Kinniburgh AJ, Maquat LE, Schedl T, Rachmilewitz E, Ross J (1982) mRNA-deficient B-thalassemia results from a single nucleotide deletion. Nucleic Acids Res 10:5421-5426.

Nunes V, Bonizzato A, Gaona A, Dognini M, Chillon M, Casals T, Pignatti PF, Novelli G, Estivill X, Gasparini P (1992) A frameshift mutation (2869insG) in the second transmembrane domain of the CFTR gene: Identification, regional distribution, and clinical presentation. Am J Hum Genet 50:11401142

Sambrook J, Fritsch EF, Maniatis T (eds) (1989) Molecular Cloning: A Laboratory Manual, 2nd ed. Cold Spring Harbor, NY: Cold Spring Harbor Laboratory Press, pp 14.14-14.17.

Shoshani T, Augarten A, Gazit E, Bashan N, Yahav Y, Rivlin Y, Tal A, Seret H, Yaar L, Kerem E, Kerem B-S (1992) Association of a nonsense mutation (W1382X), the most common mutation in the Ashkenazi Jewish cystic fibrosis patients in Israel, with the presentation of severe disease. Am J Hum Genet 50:222-228.

Spence JE, Perciaccante RG, Greig GM, Willard HF, Ledbetter $\mathrm{DH}$, Hejtmancik JF, Pollack MS, O'Brien WE, Beaudet AL (1988) Uniparental disomy as a mechanism for human genetic disease. Am J Hum Genet 42:217-226.

Strong TV, Smit LS, Turpin SV, Cole JL, Tom Hon C, Mark- 
iewicz D, Petty TL, Craig MW, Rosenow III EC, Tsui L-C, Iannuzzi MC, Knowles MR, Collins FS (1991) Cystic fibrosis gene mutation in two sisters with mild disease and normal sweat electrolyte levels. N Engl J Med 325:1630-1634.

Strong TV, Smit LS, Nasr S, Wood DL, Cole JL, Iannuzzi MC, Stern RC, Collins FS (1992) Characterization of an intron 12 splice donor mutation in the cystic fibrosis transmembrane conductance regulator (CFTR) gene. Hum Mut 1:380-387.
Tsui L-C (1992a) Mutations and sequence variations detected in the cystic fibrosis transmembrane conductance regulator (CFTR) gene: A report from the cystic fibrosis genetic analysis consortium. Hum Mut 1:197-203.

Tsui L-C (1992b) The spectrum of cystic fibrosis mutations. Trends Genet 8:392-398. 